\title{
Cholinergic control of pacemaker initiating phase III of the migrating myoelectric complex in sheep
}

\author{
K.W. Romański and P. Slawuta \\ Department of Animal Physiology, Faculty of Veterinary Medicine, \\ Wroctaw Agricultural University \\ C. Norwida 31, 50-375 Wroclaw, Poland
}

(Received 28 November 2001; revised version 18 April 2002; accepted 11 October 2002)

\section{ABSTRACT}

To estimate the region from which phase III of the migrating myoelectric complex (MMC) originates and to establish the role of nicotinic and muscarinic receptors in the initiation of this phase, chronic experiments were performed in eight sheep with bipolar platinum electrodes attached to the antral and small intestinal wall. Myoelectric activity was recorded by means of a multichannel electroencephalograph before and after slow intravenous injections of cholinergic agonists and antagonists as well as erythromycin, an agonist to the hormone motilin.

MMC phases were identified according to the criteria proposed by Code and Marlett. A total of $263 \mathrm{MMC}$ cycles was observed with a duration of $103 \pm 24$ and $91 \pm 26 \mathrm{~min}$ in fasted and non-fasted animals, respectively. In fasted sheep, $8.7 \%$ of phases III MMC originated from the pyloric antrum, $50.5 \%$ from the duodenal bulb, $29.7 \%$ from the duodenum, $8.7 \%$ from the jejunum and $2.3 \%$ from the ileum. In non-fasted sheep these values were: $10.3,31.3,39.4,15.5$ and $3.5 \%$, respectively. Neither cholinergic agonists nor erythromycin markedly changed the site of phase III MMC start. Following administration of anticholinergic drugs phase III MMC was not observed in the antrum. In fasted sheep following hexamethonium administration, $33 \%$ of phases III MMC originated from the duodenal bulb, $33 \%$ from the duodenum and $33 \%$ from the jejunum; in non-fasted sheep these values were equaled $50 \%$ each in the duodenal bulb and jejunum.

When atropine was injected into fasted sheep, $20 \%$ of phases III MMC originated from the duodenal bulb and $80 \%$ from the duodenum while in non-fasted animals $37.5,37.5$, and $25 \%$ of phases III started from the duodenal bulb, duodenum and jejunum, respectively. Following pirenzepine injection, $20 \%$ of recorded phases III MMC were induced from the duodenal bulb and $80 \%$ from the duodenum; in non-fasted animals $40 \%$ started from the duodenal bulb, $40 \%$ from the duodenum and $20 \%$ from the jejunum. The time lag from anticholinergic drug administration until the start of phase III MMC was dose-dependent and was the longest following hexamethonium administration. Thus, the ectopic pacemaker appears to be the most important in generation of phase III MMC and choli- 
nergic control of phase IIl origin from the gastrointestinal region is important in sheep. The role of nicotinic receptors seem to be greater than that of muscarinic receptors in this area.

KEY WORDS: sheep, migrating myoelectric complex, phase III, pacemaker, feeding, cholinergic drugs, erythromycin

\section{INTRODUCTION}

The migrating motor (myoelectric) complex, MMC with its four consecutive phases, including the most characteristic phase III, have been described in detail in various animal species (Szurszewski, 1969; Code and Marlett, 1975; Ruckebusch and Bueno, 1977; Bueno and Ruckebusch, 1978b; Plaza ct al., 1996a). In these animals, the substantial differences in the mode of induction and character of MMC are related to the properties of the gastrointestinal tract and feeding conditions. In monogastric animals, $\mathrm{MMC}$ arrives at relatively regular intervals only during the interdigestive period and is replaced by irregular activity after feeding. In ruminants, $\mathrm{MMC}$ is preserved during the digestive period (Ruckebusch and Bueno, 1977). Its phase III can perhaps be generated either from the stomach or from the small intestine as the so-called ectopic front (Ruckebusch and Pairet, 1984) but mostly from the duodenal bulb (Ruckebusch and Bueno, 1977). However, there are no reports of studies devoted to this problem in detail. Thus, the exact site of phase III start is not recognized in sheep. The different nature of motor activity of various segments of the gastrointestinal tract and fragmentary knowledge about the differences in controlling mechanisms between the segments imply that mechanisms initiating normal and ectopic plase III MMC can differ in sheep. Thus, the mechanisms controlling the pacemaker initiating phase III MMC in sheep are not well known.

The role of MMC in ruminants comprises both digestive and interdigestive periods, thus it is greater than in monogastric animals. Precise recognition of the mechanisms initiating phase $111 \mathrm{MMC}$ may facilitate steering the site of phase Ill origin, which is important for digesta flow, and help develop methods and tools for the treatment of relevant motility disorders. It is well known that motor function of the stomach and upper small intestine is crucial for the digestive and absorptive processes in distal segments of the gut. Increasing diagnostic possibilities in veterinary medical practice represents a specific challenge for development of gastrointestinal motility studies further elucidating the complex control mechanisms, also in ruminant species. Better understanding of these processes can identify the reference point for discernment of status from physiological conditions.

Several factors participate in the induction of phase III MMC. Motilin and the cholinergic system are the most important (Pearce et al., 1978). The role of motilin scems to be less marked in ruminants than in non-ruminant species (Ruckebusch, 
1989) but this problem has not been carefully explored in sheep. Thus erythromycin, the principal drug of the group of motilides, motilin receptor agonists, was applied to assess its possible effect on the site of phase III initiation. The role of the cholinergic system can be even more pronounced in ruminants, although the role of the vagus nerve seems not to be very important (Gregory and Miller, 1984). Therefore, it might be assumed that the role of the cholinergic system in initiation of phase III $\mathrm{MMC}$ from the specific gastrointestinal regions in ruminants is unclear.

Feeding stimulates the cholinergic system but its precise role in the gastrointestinal pacemaker initiating phase III MMC in sheep is also uncertain. Overfeeding seems to alter the MMC pattern more profoundly than normal feeding (Bueno et al., 1977; Bueno and Ruckebusch, 1978b). More recent studies provided further data suggesting that feeding can affect gastrointestinal motility in this species (Plaza et al., 1996b). Therefore, investigations were performed in moderate fasting and non-fasting periods, with and without feeding.

Besides motilin and the cholinergic system, other mechanisms are also meaningful in the control of phase III MMC. They include opioid and serotoninergic control mechanisms and the role of other hormones like somatostatin seems to be marked in sheep (Ruckebusch, 1989).

Thus, the aim of this work was to provide new data describing the precise site of phase III start and its delay under various feeding conditions, cholinergic stimulation and cholinergic blockade, and to elucidate the role of motilin in this scope, in sheep.

\section{MATERIAL AND METHODS}

\section{Animal preparation}

The chronic experiments were performed on eight adult Polish Merino sheep weighing 40-45 kg each. $24 \mathrm{~h}$ fasted animals underwent surgical implantation of bipolar platinum electrodes to the distal stomach and small intestine. Seven serosal electrodes were attached onto the: 1) antrum, $4 \mathrm{~cm}$ proximally to the pyloric ring; 2) duodenal bulb, $6 \mathrm{~cm}$ distally to the pylorus; 3 ) duodenum, $50 \mathrm{~cm}$ distally to electrode 2 ; 4) jejunum $1,200 \mathrm{~cm}$ distally to electrode $3 ; 5)$ jejunum $2,100 \mathrm{~cm}$ distally to electrode $4 ; 6$ ) ileum $1,110 \mathrm{~cm}$ proximally to the ileo-cecal sphincter; 7) ileum $2,100 \mathrm{~cm}$ distally to electrode 6 (Figure 1). The electrode wires, marked for recognition, were exteriorized $2-3 \mathrm{~cm}$ near the incision line on the right side of the abdomen and were fixed to the skin. Then, with the sutures completed, the animals were allowed 14 days for recovery. Drinking water was not limited. 2-4 days following the surgery, feeding with hay was started and within a few days the amount of hay reached a rate of $2 \mathrm{~kg}$ per animal daily. The animals were also fed with standard grain mixture ( $3-5 \mathrm{~g} / \mathrm{kg}$ of body weight). 


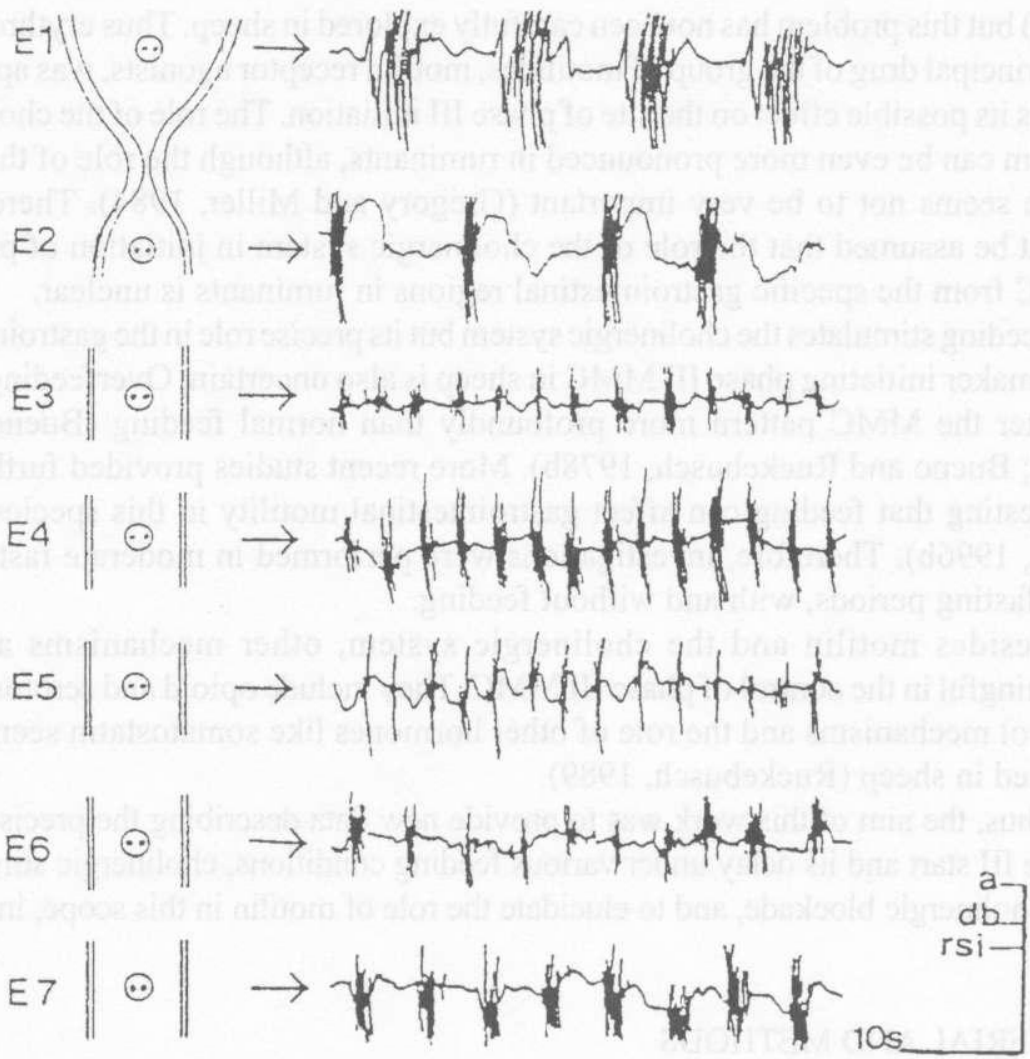

Figure 1. Localization of electrodes in ovine gastrointestinal tract (circle bottons) and the fragments of the recordings of continuous spiking activity (pyloric antrum) or the recordings of phase III MMC (small bowel regions) from every electrode depicted. Examples of myoelectrical recordings were taken from the same control experiment performed in non-fed and non-fasted sheep.

Explanation of symbols. Electrodes: E1 - electrode in pyloric antrum, E2 - duodenal bulb, E3 - duodenum, E4 and E5 - jejunum, E6 and E7 - ileum. Calibration $100 \mu \mathrm{V}$ : a - pyloric antrum (17 mm per 100 $\mu \mathrm{V}$, at speed of paper $2.5 \mathrm{~mm} / \mathrm{s})$, db - duodenal bulb $(13 \mathrm{~mm}$ per $100 \mu \mathrm{V})$, rsi - remaining small intestine $(10.5 \mathrm{~mm}$ per $100 \mu \mathrm{V})$. Time bar $-10 \mathrm{~s}$. Further description as in the chapter Material and Methods

\section{Experiments}

During the experiments lasting 2-7 h each, myoelectric activity was recorded in habituated animals, using a multichannel electroencephalograph (Reega Duplex TR XVI, Alvar Electronic, Paris) with a paper speed of $2.5 \mathrm{~mm} / \mathrm{s}$ and time constant $0.01 \mathrm{~s}$ to obtain clear recordings (Figure 1). The migrating myoelectric complex (MMC) and its phases were identified according to the criteria proposed by Code and Marlett (1975). At least 1-2 day intervals were allowed between two consecutive experiments 
performed on the same animal. Experiments were carried out in random order and were divided into two main groups, i.e. on animals fasted $48 \mathrm{~h}$ and on non-fasted animals. During the control recordings in all the studied animals, at least two normal phases III MMC were recorded in most experiments. All the experiments were performed with or without feeding, before and after slow intravenous injection of agonists and antagonists of the cholinergic system. Only the first MMC cycle including the first phase III MMC that occurred following the given procedure was analyzed. Evaluation of the drug effect was started from the end of drug administration. Most experiments were repeated 2-6 times on each animal studied.

\section{Drugs}

The following drugs were used: 1) cholinergic agonists - acetylcholine chloride (ACh, Sigma) 10,30 or $50 \mu \mathrm{g} / \mathrm{kg}$ of body weight; dimethylpiperazine iodide (DMPP, RBI) $12.5,30$ or $100 \mu \mathrm{g} / \mathrm{kg}$ of body weight; bethanechol chloride (Be, Sigma) $12.5,30$ or $100 \mu \mathrm{g} / \mathrm{kg}$ of body weight; 2) cholinergic antagonists - hexamethonium bromide (Hx, Sigma) $1.0,2.0$ or $5.0 \mathrm{mg} / \mathrm{kg}$ of body weight; atropine sulphate (At, Polfa) $0.02,0.1$ or $0.5 \mathrm{mg} / \mathrm{kg}$ of body weight; pirenzepine dilyydrochloride (Pi, Sigma) $0.02,0.1$ or $0.5 \mathrm{mg} / \mathrm{kg}$ of body weight; 3) motilin receptor agonist - erythromycin lactobionate (Er, Polfa) $12.5,30$ or $100 \mu \mathrm{g} / \mathrm{kg}$ of body weight. The drugs were administered during phase II MMC, 20-30 min after termination of phase I MMC. The duration of drug infusions was: 0.5-1.0 min for low doses, 1.5-2.0 min for moderate doses and 3.0-6.0 min for high doses.

\section{Analysis of results}

MMC and its phases were identified and the duration of MMC cycles and the site of initiation of phase III MMC were analyzed in the each experimental group. The results were statistically elaborated and presented as mean values with standard deviation or as the percentage of total value in the consecutive experimental groups. Student's $t$-test for unpaired values was used where appropriate. Values obtained during the experiments were compared with control values obtained from the same sheep.

\section{RESULTS}

A total of $263 \mathrm{MMC}$ cycles was recorded during the experiments. In fasted animals, $104 \mathrm{MMCs}$ lasting $103 \pm 24 \mathrm{~min}$ and in non-fasted animals, $159 \mathrm{MMCs}$ lasting $91 \pm 26 \mathrm{~min}$ (N.S.) were recorded during control experiments. In fasted animals, phase III MMC arrived 105.6 $27.0 \mathrm{~min}$ after feeding while in non-fasted animals phase III MMC arrived $63.7 \pm 13.4$ min after feeding $(\mathrm{P}<0.05)$. 
In fasted animals, phase III MMC originated mostly from the duodenal bulb (Table 1). Feeding tended to lower this site to the duodeno-jejunum. In non-fasted animals, phase III MMC started mostly from the duodenal bulb and the duodenum, and feeding did not markedly alter this site. In non-fed animals, about $10 \%$ of MMC phases IIIs originated from the antrum and no phase III MMC was observed in the antrum after feeding (Table 1).

TABLE 1

Site of phase III MMC origin in fasted (F) and non-fasted (N - F) sheep, before and after feeding expressed in per cent of total number of observations (n)

\begin{tabular}{|c|c|c|c|c|}
\hline & \multicolumn{2}{|c|}{ Before feeding } & \multicolumn{2}{|c|}{ After feeding* } \\
\hline & $\mathrm{F}$ & $\mathrm{N}-\mathrm{F}$ & $\mathrm{F}$ & $\mathrm{N}-\mathrm{F}$ \\
\hline Antrum & 8.7 & 10.3 & 0 & 0 \\
\hline Duodenal bulb & 50.5 & 31.3 & 32.3 & 41.2 \\
\hline Duodenum & 29.7 & 39.4 & 38.7 & 35.3 \\
\hline Jejunum & 8.7 & 15.5 & 12.9 & 23.5 \\
\hline Ileum & 2.3 & 3.5 & 16.1 & 0 \\
\hline $\mathrm{n}$ & 63 & 102 & 31 & 17 \\
\hline
\end{tabular}

*first phase III MMC arriving after feeding was considered

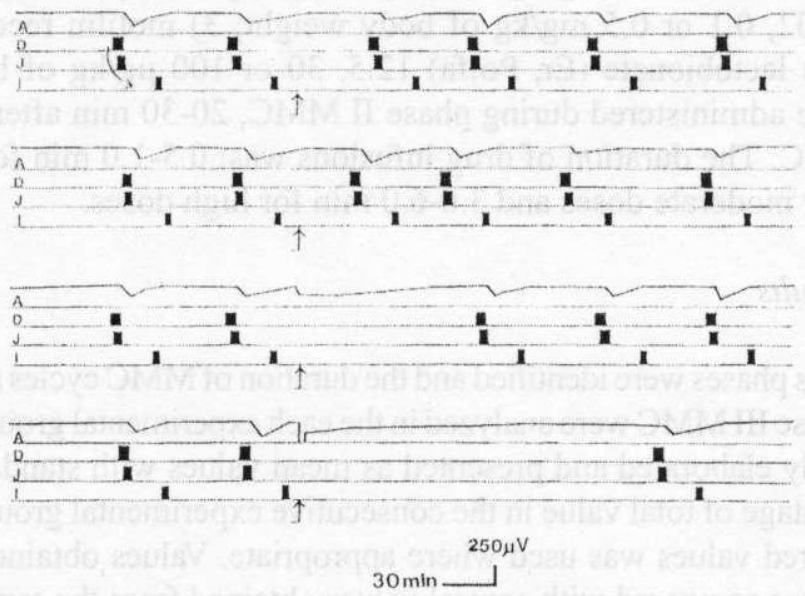

Figure 2. Scheme of myoelectrical activity of the ovine pyloric antrum (A, open irregular bars indicate continuous or almost continuous spiking activity with changeable amplitude; no distinct phase III $\mathrm{MMC}$ can be distinguished in this region), duodenum (D), jejunum (J) and ileum (I). Closed squares of rectangles indicate phase III MMC in these small intestinal regions. Drug (DMPP and hexamethonium bromide, $\mathrm{Hx}$ ) administration following the control recording indicated by arrows. Four panels present four experiments performed on the same non-fed and non-fasted sheep. From top to bottom: panel 1 - DMPP administration at the dose $12.5 \mu \mathrm{g} / \mathrm{kg}$ i.v.; panel 2 - DMPP, $100 \mu \mathrm{g} / \mathrm{kg}$; panel 3 - $\mathrm{Hx}, 1.0$ $\mathrm{mg} / \mathrm{kg}$; panel 4 - $\mathrm{Hx}, 5.0 \mathrm{mg} / \mathrm{kg} \mathrm{BW}$.

Explanation of symbols: A - antral electrode (E1), D - duodenal electrode (E3), J - jejunal electrode (E5), I - ileal electrode (E6). Calibration $250 \mu \mathrm{V}$. Time bar - $30 \mathrm{~min}$.

Further description as in the chapter Material and Methods 
TABLE 2

Site of origin of first phase III MMC arrived after various doses of cholinergic agonists and erythromycin in fasted $(F)$ and non-fasted (N-F) sheep expressed in per cent of total number of observations (1)

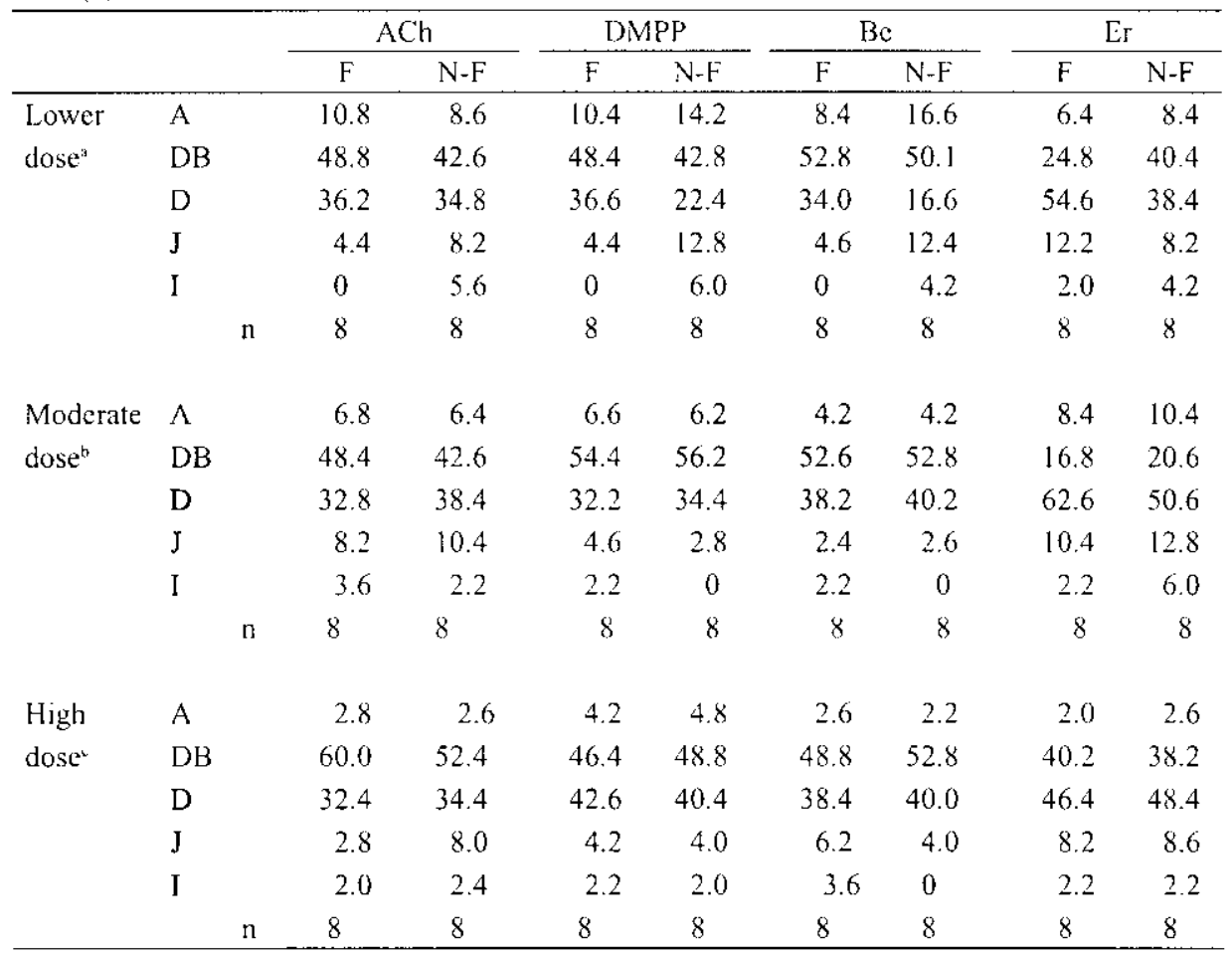

A - antrum, DB - duodenal bulb, D - duodenum, J - jejumum, 1 - ileum. $\mathrm{ACh}$ - acetylcholine chlorjde, Be - bethanechol chloride, Er - erythromycin lactobionate

"lower doses: $10 \mu \mathrm{g} / \mathrm{kg}$ for $A C h, 12.5 \mu \mathrm{g} / \mathrm{kg}$ for other drugs; " moderate doses: $30 \mu \mathrm{g} / \mathrm{kg}$; "high doses: 50 $\mu \mathrm{g} / \mathrm{kg}$ for $\Lambda \mathrm{Ch}, 100 \mu \mathrm{g} / \mathrm{kg}$ for other drugs. Other explanations, sec chapter Material and Methods

After low doses of cholinergic stimulatory substances and erythromycin, the number of phases III MMC starting from various levels of the gastrointestinal tract was not markedly different from controls both in fasted and non-fasted sheep (Table 2, Figure 2). High doses of these drugs lowered the number of phases III MMC starting from the antrum.

Following administration of drugs blocking cholinergic receptors, only ectopic phases III MMC were observed. After administration of hexamethonium at the lower dose, all MMC phase IIIs originated from the duodenum (Figure 2). The higher dose lowered the site of start of two-thirds of these phases in fasted animals and half of phases III MMC in non-fasted animals (Table 3). 
TABLE 3

Site of origin of first phase III MMC arrived after various doses of cholinergic antagonists in fasted (F) and non-fasted (N-F) sheep expressed in per cent of total number of observations (n)

\begin{tabular}{|c|c|c|c|c|c|c|c|c|}
\hline & & & \multicolumn{2}{|c|}{$\mathrm{Hx}$} & \multicolumn{2}{|c|}{ At } & \multicolumn{2}{|c|}{$\mathrm{p}$} \\
\hline & & & $\mathrm{F}$ & N-F & $\mathrm{F}$ & N-F & $F$ & N-F \\
\hline Lower & A & & 0 & 0 & 0 & 0 & 0 & 0 \\
\hline $\operatorname{dose}^{a}$ & DB & & 0 & 0 & 75.0 & 0 & 50.0 & 37.5 \\
\hline & D & & 100 & 100 & 25.0 & 75.0 & 50.0 & 62.5 \\
\hline & $\mathrm{J}$ & & 0 & 0 & 0 & 25.0 & 0 & 0 \\
\hline & I & & 0 & 0 & 0 & 0 & 0 & 0 \\
\hline ( & & $\mathrm{n}$ & 8 & 8 & 8 & 8 & 8 & 8 \\
\hline Moderate & A & & 0 & 0 & 0 & 0 & 0 & 0 \\
\hline $\operatorname{dose}^{b}$ & DB & & 33.0 & 50.0 & 20.0 & 37.5 & 20.0 & 40.0 \\
\hline & D & & 33.0 & 0 & 80.0 & 37.5 & 80.0 & 40.0 \\
\hline & J & & 0 & 50.0 & 0 & 25.0 & 0 & 20.0 \\
\hline & I & & 33.0 & 0 & 0 & 0 & 0 & 0 \\
\hline & & $\mathrm{n}$ & 9 & 8 & 10 & 8 & 10 & 8 \\
\hline High & A & & 0 & 0 & 0 & 0 & 0 & 0 \\
\hline dose $e^{c}$ & DB & & 60.0 & 56.0 & 62.5 & 37.5 & 37.5 & 25.0 \\
\hline & D & & 40.0 & 44.0 & 0 & 62.5 & 62.5 & 62.5 \\
\hline & $\mathrm{J}$ & & 0 & 0 & 0 & 0 & 0 & 12.5 \\
\hline & I & & 0 & 0 & 37.5 & 0 & 0 & 0 \\
\hline & & $\mathrm{n}$ & 8 & 8 & 8 & 8 & 8 & 8 \\
\hline
\end{tabular}

A - antrum, DB - duodenal bulb, D - duodenum, J - jejunum, I - ileum. Hx - hexamethonium bromi$\mathrm{de}, \mathrm{At}$ - atropine sulphate, $\mathrm{Pi}$ - pirenzepine dihydrochloride

${ }^{\mathrm{a}}$ lower doses: 1.0, 0.02, and $0.02 \mathrm{mg} / \mathrm{kg}$; ${ }^{\mathrm{b}}$ moderate doses: $2.0,0.1$ and $0.1 \mathrm{mg} / \mathrm{kg}$; ${ }^{\mathrm{c}}$ high doses: $5.0,0.5$ and $0.5 \mathrm{mg} / \mathrm{kg}$ for $\mathrm{Hx}$, At and $\mathrm{Pi}$, respectively

Following atropine administration, the percentage of phases III MMC starting from the lower intestinal segments tended to increase along with the increase of the drug's dose (Table 3). A similar tendency was observed after pirenzepine administration but the results were less consistent (Table 3). Following administration of antimuscarinic drugs in fasted animals a higher percentage of phases III MMC originated from the duodenum than in non-fasted sheep.

After administration of cholinergic stimulatory substances and erythromycin, phase III MMC exhibited a tendency to arrive within a shorter time than during the relevant control periods; the results were usually dose-dependent (Table 4, Figure 2).

Administration of drugs blocking cholinergic receptors delayed dose-dependently the arrival of phase III MMC; the results obtained in non-fasted animals were more 
pronounced than in fasted animals (Table 4). Low doses of pirenzepine exerted a weaker effect than higher doses. Pirenzepine administration at both higher doses provided similar results. There were no marked differences between the values obtained from the experiments performed on fasted and non-fasted sheep (Table 4). The different effect of stimulatory and inhibitory drugs on phase III start is illustrated in Figure 2.

TABLE 4

Time lag elapsed from the end of drug administration till arrival of first phase III MMC in fasted (F) and non-fasted (NF) sheep expressed in minutes

\begin{tabular}{|c|c|c|c|c|c|c|c|c|c|c|}
\hline & \multirow{2}{*}{$\mathrm{F}$} & \multirow{2}{*}{ mean } & & $\Lambda \mathrm{Ch}$ & DMPP & $\mathrm{Be}$ & $\mathrm{Er}$ & $\mathrm{Hx}$ & $\Lambda \mathrm{t}$ & $\mathrm{Pi}$ \\
\hline & & & & 64 & 43 & 36 & 52 & 104 & 46 & 56 \\
\hline Lower & & $\pm \mathrm{SD}$ & & 18 & 8 & 5 & 6 & 24 & 19 & 16 \\
\hline \multirow[t]{4}{*}{ dose } & $\mathrm{NF}$ & mean & & 61 & 48 & 37 & 48 & $134^{*}$ & $74 *$ & 73 \\
\hline & & $\pm \mathrm{SD}$ & & 14 & $1 !$ & 8 & 4 & 20 & 15 & 19 \\
\hline & & & $\mathrm{n}$ & 8 & 8 & 8 & 8 & 8 & 8 & 8 \\
\hline & $\mathrm{F}$ & mean & & 48 & 39 & 28 & 45 & 162 & 73 & $7 !$ \\
\hline Moderate & & $\pm \mathrm{SD}$ & & 12 & 10 & 6 & 19 & 14 & 18 & 17 \\
\hline \multirow[t]{4}{*}{ dose } & NF & mean & & 42 & 38 & 26 & 48 & 184 & $101^{*}$ & $102^{*}$ \\
\hline & & $\pm \mathrm{SD}$ & & 12 & 6 & 4 & 21 & 43 & 25 & 23 \\
\hline & & & $\mathrm{n}$ & 8 & 8 & 8 & 8 & 8 & 8 & 8 \\
\hline & $F$ & mean & & 44 & 32 & 24 & 22 & 187 & 74 & 85 \\
\hline High & & $\pm \mathrm{SD}$ & & 10 & 6 & 4 & 6 & 25 & 20 & 12 \\
\hline \multirow[t]{3}{*}{ dose } & NF & mean & & 40 & 28 & 20 & 18 & $256^{* *}$ & $105^{*}$ & $103^{*}$ \\
\hline & & $\pm \mathrm{SD}$ & & 16 & 6 & 4 & 4 & 34 & 9 & 11 \\
\hline & & & $\mathrm{n}$ & 8 & 8 & 8 & 8 & 8 & 8 & 8 \\
\hline
\end{tabular}

${ }^{*} \mathrm{P}<0.05 ;{ }^{* *} \mathrm{P}<0.01$ vs relevant $\mathrm{F}$ value

other explanations, see Tables 2 and 3, and chapter Material and Methods

\section{DISCUSSION}

The obtained results suggest that the duodenum and the duodenal bulb in particular, is the most common but not the only site of initiation of phase III MMC in sheep. Ruckebusch and collaborators (Ruckebusch and Bueno, 1977; Ruckebusch and Bardon, 1984) stated that phase III MMC starts exclusively from the duodenal bulb, which remains, in part, in contrast with the present study. Spontaneous phase III MMC starting from a level below duodenal bulb has not 
been described in sheep. With the exception of one report (Ruckebusch and Pairet, 1984), where spontaneous phase III MMC starting just before the pyloric ring was shown, starting of phase III MMC from the stomach has not been demonstrated. The present study showed that spontaneous phase III MMC can start either from ovine pyloric antrum or from the lower parts of the small intestine decreasing the difference between ruminant and non-ruminant species in this area. In monogastrics, during the interdigestive state the acidic content can stimulate motilin release, which is responsible for oceurrence of phase III MMC in the stomach (Itoh et al., 1980). It is also known that the ectopic front is quite frequent event in these species (Sarna, 1985). In ruminants, the role of motilin in the initiation of phase III MMC from the stomach seems to be limited (Ruckebusch, 1989; Plaza et al., 1996a) since the almost continuously flowing abomasal content is less acidic. However, the $\mathrm{pH}$ is low in the abomasum and proximal duodenum in sheep and gastric acid can inhibit abomasal motility and, in turn, initiate phase III MMC from the duodenal bulb (Gregory and Miller, 1984). These findings remain in concert with the results of Calignosan et al. (1984) who performed an immunocytochemical study and found that motilin-producing cells are absent in the ovine abomasum. The lack of a significant effect of erythromycin administration, the principal representative of motilides, upon the site of phase III origin in the present study further confirms the previous findings regarding the role of motilin in the control of $\mathrm{MMC}$ in sheep. However, it is unclear whether secreted acid can affect intestinal motility only via motilin release or perhaps other mechanisms also participate in this response. It is possible that motilin can be released locally by mechanical factors.

The effect of feeding on MMC in sheep was reported by several authors (Bueno and Ruckebusch, 1978b; Lester and Bolton, 1994). Principally, feeding does not abolish MMC in ruminants but, as in monogastric animals it appears to stimulate the cholinergic system and digestive hormone release (see below), thus involving several regulatory mechanisms. Therefore, the precise interpretation of the effect evoked by feeding is difficult. Food is a strong stimulus to gastrointestinal motility, thus the lack of phase III $\mathrm{MMC}$ in the antrum observed in the present study during control experiments after feeding coincides with the decreasing number of phases III MMC in the antrum along with the increased doses of stimulatory substances. Stronger stimulation can also trigger factors inhibiting phase $I 11 \mathrm{MMC}$ in the antrum and/or factors stimulating phase III MMC in the small intestine. As was reported by Ruckebusch and Pairet (1984), antral and duodenal motility are coordinated. When phase III MMC is present in the duodenum, antral activity is periodically ceased. Food-provoked abomasal distension might induce abomasal emptying thus stimulating the propulsive motility but the effect of gastric distension on initiation of phase III MMC has not been reported. The role of cholinergic mechanisms (Bucno and Ruckebusch, 1978a; Ruckebusch et al., 1987) and direct or indirect release of gastrointestinal hormones including gastrin, cholecystokinin, pancreatic polypeptide, somatostatin and insulin (Walsh, 1994; Plaza 
et al., 1996a,b) can be considered important events in these circumstances.

Acetyleholine and DMPP administration did not exert any significant effect on the site of phase III MMC initiation. Nicotine can inhibit antral motility probably due to its action on nicotinic receptors present in adrenergic ganglia. Thus, this action can neutralize the influences upon the cholinergic intramural ganglia of the enteric nervous system. Low and moderate doses of hexamethonium inhibited phase Ill $\mathrm{MMC}$ in the gastroduodenal region more strongly than the muscarinic antagonists. Hexamethonium inhibited the arrival of phase III MMC for a longer period than the antimuscarinic drugs. The nicotinic receptors are present in intramural ganglia projecting to the smooth muscles with the effercnt neural fibres that are cholinergic in part. Muscarinic receptors are mostly localized closely to the smooth muscle. Thus, the effects mediated by intramural ganglionic nicotinic receptors could be transmitted through the efferent neural fibres to a broader region than muscarinic effects and be more pronounced. The present study provided meaningful cvidence that the cholinergic system is directly responsible for the initiation of phase III MMC and that the role of nicotinic receptors is more pronounced than that of muscarinic receptors in this area.

There were no marked differences between the effects of atropine and pirenzepine on the site of the origin of phase III. Atropine is an unspecific muscarinic blocker while pirenzepine can distinguish between some muscarinic receptor subtypes. Pirenzepine was thought to be able to engage principally the $M_{1}$ cholinergic receptor subtype. It was found by Schiavone et al. (1989) that pirenzepine at a small dose blocked $\mathrm{M}_{1}$ cholinergic receptors influencing $\mathrm{MMC}$ in the dog. More recent data indicate that pirenzepine can act also on other muscarinic receptor subtypes and it was confirmed that atropine is an unspecific muscarinic receptor antagonist (Shi and Sarna, 1997). The obtained results suggest that were no specific differences in pirenzepine action when the drug was given in various doses. Thus, pirenzepine exerted its action through the muscarinic receptors other than of $\mathrm{M}_{1}$ subtype. Almost nothing is known regarding the possible role of muscarinic receptor subtypes in the inhibition of phase III MMC and the site of the origin of phase III MMC in sheep. A recent study provided some data that cholinergic muscarinic receptor subtypes can differ in their role in gastroduodenal coordination in this species (Romański and Sławuta, 2001). Therefore, the problem warrants further investigation.

It is well known that not only motilin and cholinergic mechanisms are important for the site of phase III origin, i.e. for the initiation of phase III (Sarna, 1985; Ruckebusch, 1989). Opioid and serotoninergic mechanisms and some gut hormones, including somatostatin were also reported to be important (Ruckebusch and Bardon, 1984; Plaza, 1996a). As motilin action can be exerted directly on the smooth muscles and indirectly, through the cholinergic system, there is also evidenec for the cooperation between other important mechanisms in their control of gastrointestinal motility due to the presence of cholinergic interneurons within 
the enteric nervous system connected with non-adrenergic non-cholincrgic (NANC) neurons (Vizi et al., 1984; Grider, 1994). The effect of such cooperation can either be stimulatory or inhibitory, which can be illustrated by the reported inconsistent effect of vagotomy on gastrointestinal motility (Gregory et al., 1984; Malbert and Ruckebusch, 1989). Thus, it can be concluded that the cholinergic system may participate directly and indirectly in the control of gastrointestinal motility, including the MMC pattern and further extensive studies are necessary to elucidate its precise role in sheep.

The presented results indicate that the duodenal pacemaker area is the most important in the initiation of phase III MMC in sheep and the role of cholinergic mechanisms in the control of this event is complex. It might be more pronouneed in the antrum than in the small intestine where other mechanisms may have the principal role in the initiation of phase III MMC (Ruckebusch, 1989).

\section{REFERENCES}

Bueno L., Ruckebusch Y., 1978a. Effect of anticholinergic drugs on the electrical activity of the antrum and duodeno-jejunum in sheep. J. Vet. Pharmacol. Ther. 1, 225-232

Bueno L., Ruckebusch Y., 1978b. Migrating myoelectrical complexes: distuption, enhancement and disorganization. In: H.L. Duthie (Editor). Gastrointestinal Motility in Health and Disease. MTP Press Ltd., Lancaster, pp. 83-91

Bueno L., Weekes T.E.C., Ruckebusch Y., 1977. Effects of diet on the motility of the small intestine and plasma insulin levels in sheep. Ann. Rech. Vet. 8, 95-104

Calignosan N.Y., Kitamura N., Yamada J., Ooomori Y., Yamashita T., 1984. Immunocytochemical study on the gastroenteropancreatic endocrine cells of the sheep. Acta Anat. 118, 171-180

Code C.F., Marlett J.A., 1975. The interdigestive myoclectric complex of the stomach and small bowel of dogs. J. Physiol. 246, 289-309

Gregory P.C., Rayner D.V., Wenham G., 1984. Initiation of migrating myoelectric complex in sheep by duodenal acidification and hyperosmolarity: role of vagus nerves. J. Physiol. 355, 509-52 1

Grider J.R., 1994. Interplay of somatostatin, opioid, and GABA neurons in the regulation of the peristaltic refex. Amer. J. Physiol. 267. G696-G701

Itoh Z., Aizawa 1., Takeuchi S., Honda R., Takahashi I., Mori K., 1980. Mechanism by which the interdigestive motor pattern becomes irregular in conscious dogs. ln: J. Christensen (Editor). Gastrointestinal Motility. Raven Press, New York, pp. 279-286

Lester G.D., Bolton J.R., 1994. Effect of dietary composition on abomasal and duodenal myoclectrical activity. Res. Vet. Sci, 57, 270-276

Malbert C.H., Ruckebusch Y., 1989. Vagal influences on the phasic and tonic components of the motility of the ovine stomach and gastroduodenal area. J. Gastrointest. Moti1. 1, 15-20

Pearce E.A.N., Wingate D.L., Wunsch E., 1978. The cffects of gastrointestinal hormones and feeding on the basic electrical rhythm of the stomach and duodenum of the conscious dog. J. Physiol. 276,41 
Plaza M.A., Arruebo M.P., Murillo M.D., 1996b. Involvement of somatostatin, bombesin and serotonin in the origin of the migrating myoelectric complex in sheep. Life Sci. 58, 2155-2165

Plaza M.A., Arruebo M.P., Sopena J., Bonafonte J.I., Murillo M.D., 1996c. Myoelectrical activity of the gastrointestinal tract of sheep analysed by computer. Res. Vet. Sci. 60, 55-60

Romański K.W., Sławuta P., 2001. Role of cholinergic receptor subtypes upon the antroduodenal coordination in sheep. J. Physiol. Pharmacol. 52, Suppl. II, 47 (Abstr.)

Ruckebusch Y., 1984. Enhancement of the cyclic motor activity of the ovine small intestine by lysergic acid derivatives. Mechanism and significance. Gastroenterology 87, 1049-1055

Ruckebusch Y., 1989. Gastrointestinal motor function in ruminants. In: S.G. Schultz (Editor). Handbook of Physiology. Sect. 6. American Physiological Society, Bethesda, pp. 1225-1282

Ruckebusch Y., Bardon T., 1984. The cyclic motor activity in the ovine gut: its reset at a faster rhythm. Experientia 40, 819-820

Ruckebusch Y., Bueno L., 1977. Origin of migrating myoelectrical complex in sheep. Amer. J. Physiol. 233, E483-E487

Ruckebusch Y., Malbert C.H., Crichlow E.C., 1987. Hexamethonium: a probe to assess autonomic nervous system involvement in upper gastrointestinal functions in conscious sheep. Vet. Res. Commun. 11, 293-303

Ruckebusch Y., Pairet M., 1984. Duodenal bulb motor activity in sheep. Zbl. Vet. Med. A 31, 401413

Sarna S.K., 1985. Cyclic motor activity; migrating motor complex. Gastroenterology 89, 894-913

Schiavone A., Sagrada A., Pagani F., Giachetti A., 1989. Role of muscarinic receptor subtypes in the regulation of migrating myoelectric complex in the dog. Gastroenterology 96, 116-121

Shi X.-Z., Sarna S.K., 1997. Inflammatory modulation of muscarinic receptor activation in canine ileal circular muscle. Gastroenterology 112, 864-874

Szurszewski J.H., 1969. A migrating electric complex of the canine small intestine. Amer. J. Physiol. 217, 1757-1763

Vizi E.S., Ono K., Adam-Vizi V., Duncalf D., Foldes F.F., 1984. Presynaptic inhibitory effect of met-enkephalin on $\left[{ }^{14} \mathrm{C}\right]$ acetylcholine release from the myenteric plexus and its interaction with muscarinic negative feedback inhibition. J. Pharmacol. Exp. Ther. 230, 493-499

Walsh J.H., 1994. Gastrointestinal hormones. In: L.R. Johnson (Editor). Physiology of the Gastrointestinal Tract. Raven Press, New York, pp. 1-128

\section{STRESZCZENIE}

Cholinergiczna kontrola rozrusznika inicjującego fazę III wędrującego kompleksu mioelektrycznego u owcy

W celu ustalenia rejonu inicjowania fazy III wędrującego kompleksu mioelektrycznego (MMC) i sprecyzowania roli cholinergicznych receptorów nikotynynowych i muskarynowych w inicjowaniu wspomnianej fazy, przeprowadzono chroniczne doświadczenia na 8 owcach z wszczepionymi elektrodami bipolarnymi do ściany jamy odźwiernikowej i jelita cienkiego. Aktywność mioelektryczną z tych rejonów rejestrowano przy pomocy wielokanałowego elektroencefalografu, przed i po powolnym dożylnym podaniu cholinergicznych agonistów i antagonistów oraz agonisty receptora motylinowego, laktobionianu erytromycyny. Fazy MMC różnicowano stosując kryteria zaproponowane przez Code'a i Marlett. Łącznie obserwowano 263 cykle MMC, trwające odpowiednio u owiec głodzonych i nie 
głodzonych $103 \pm 24$ min i $91 \pm 26$ min. L owiec glodzonych start fazy 111 MMC następował w $8.7 \%$ z. jany odźwienikowej, $50,5 \%$ z opuscki dwunastnicy. $29,7 \%$ z dwunasmicy, $8.7 \%$ z jelita czcrego i $2,3 \%$ z jelita biodrowego. U owiec nie glodzonych odsetek rozpoczynających się faz Ill wynosif odpowiednio: 10,$3 ; 31,3 ; 39,4 ; 15,5$ i 3,5 . Po podaniu środków antycholinergicznych faza lll MMC w rejonic jamy odźwiemikowej nie występowała. Po podaniu heksametonium start tazy I[l następował u owiec głodzonych w $33 \%$ z opuszki dwunastnicy, w 33\% z dwunastnicy i w 33\% z jelita biodrowego, a u nie glodzonych w $50 \%$ z opuszki dwunastnicy i w 50\% 7 jelita czczego. Po podaniu atropiny starl fazy III następował u owicc głodzonych w $20 \%$ z opuszki dwunastnicy i w $80 \%$ z dwunastnicy dalszej, a u owiec nie głodzonych w $37,5 \%$ z opuszki dwunastnicy, w $37,5 \%$ z dwunastnicy i w $25 \%$ 7. jelita czczego. Po zastosowaniu pirenzepiny faza Ill rozpoczynała się u owiec głodzonych w $20 \%$ z opuszki dwunastnicy i w $80 \%$ z dwunastnicy, a u nic głodzonych w $40 \%$ z opuszki dwunastnicy, w $40 \%$ z dwunastnicy i w $20 \%$ z jelita czczego. Długość okresu od podania środka antycholinergicznego do pojawienia siç fazy III MMC zależała od dawki i była najdłuższa po podaniu heksametonium. Pozaszczytowy rozrusznik wydaje się być zatem najbardziej istotny w inicjowaniu fazy III MMC u owcy, podczas gdy układ cholinergiczny wydaje siç micć najwiçkszy wpływ na inicjowanie fazy III MMC z rejonu jamy odźwiemikowej u tego gatunku. Rola nikotynowych receptorów wydaje sį̨ byc większa w tym zakresic niż receptorów muskarynowych. 